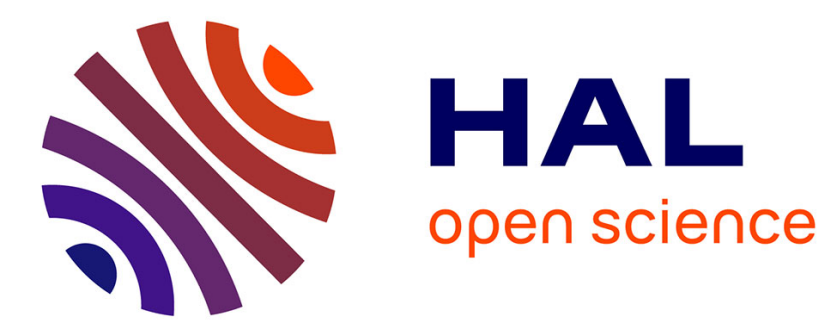

\title{
Intraspecific variability in leaf traits strongly affects alder leaf decomposition in a stream
}

\author{
Antoine Lecerf, Eric Chauvet
}

\section{To cite this version:}

Antoine Lecerf, Eric Chauvet. Intraspecific variability in leaf traits strongly affects alder leaf decomposition in a stream. Basic and Applied Ecology, 2008, vol. 9 ( $\mathrm{n}^{\circ}$ 5), pp. 598-605. 10.1016/j.baae.2007.11.003 . hal-01312780

\section{HAL Id: hal-01312780 \\ https://hal.science/hal-01312780}

Submitted on 9 May 2016

HAL is a multi-disciplinary open access archive for the deposit and dissemination of scientific research documents, whether they are published or not. The documents may come from teaching and research institutions in France or abroad, or from public or private research centers.
L'archive ouverte pluridisciplinaire HAL, est destinée au dépôt et à la diffusion de documents scientifiques de niveau recherche, publiés ou non, émanant des établissements d'enseignement et de recherche français ou étrangers, des laboratoires publics ou privés. 


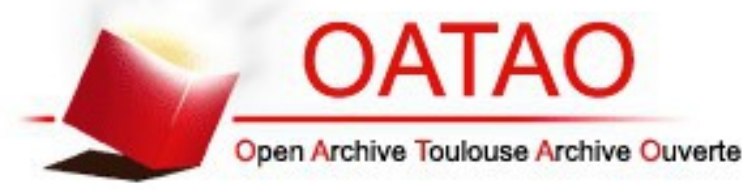

\section{Open Archive TOULOUSE Archive Ouverte (OATAO)}

OATAO is an open access repository that collects the work of Toulouse researchers and makes it freely available over the web where possible.

This is an author-deposited version published in : http://oatao.univ-toulouse.fr/ Eprints ID : 9667

To link to this article : DOI :10.1016/j.baae.2007.11.003

URL : http://dx.doi.org/10.1016/j.baae.2007.11.003

To cite this version : Lecerf, Antoine and Chauvet, Eric Intraspecific variability in leaf traits strongly affects alder leaf decomposition in a stream. (2008) Basic and Applied Ecology, vol. 9 (n 5). pp. 598-605. ISSN 1439-1791

Any correspondance concerning this service should be sent to the repository administrator: staff-oatao@,listes-diff.inp-toulouse.fr 


\title{
Intraspecific variability in leaf traits strongly affects alder leaf decomposition in a stream
}

\author{
Antoine Lecerf*, Eric Chauvet \\ EcoLab - Laboratoire d'écologie fonctionnelle, UMR 5245 (CNRS-UPS-INPT), 29 rue Jeanne Marvig, \\ 31055 Toulouse Cedex, France
}

\begin{abstract}
This study assessed the intraspecific variability of senescent leaves of alder (Alnus glutinosa Gaertn.) and the effects of this variability on leaf decomposition in streams. Leaves were collected at five geographically distant locations in Europe. We analyzed 10 batches of leaf samples for seven quantitative leaf traits as well as leaf decomposition rate in coarse and fine mesh bags exposed in a single stream. The geographic origin of leaf samples largely explained the observed variation in litter quality and decomposition rate. Phosphorus $(0.034-0.187 \%)$ and lignin $(3.9-18.7 \%)$ concentrations in leaves varied widely. Together, these two traits accurately predicted leaf decomposition rate $\left(r^{2}=84.1 \%\right)$. Intraspecific variation in leaf decomposition rate was within a range similar to that reported for interspecific variation a mong cooccurring riparian plant species in Europe. Our study demonstrates extensive intraspecific variability in leaf traits on a continental scale, which can have enormous effects on major ecosystem processes such as leaf decomposition.
\end{abstract}

\section{Zusammenfassung}

Die vorliegende Studie untersucht die Variabilität von Erlenfalllaub (Alnus glutinosa Gaertn.), das an fünf Orten von Schweden bis Portugal gesammelt wurde, und ihren Einfluss a ufd ie S treuzersetzung. W ir a nalysierten zehn Blattproben in Hinblick auf sieben quantitative Blatteigenschaften und die Abbauraten in groben und feinen Netzbeuteln nach Ausbringung in einem Fluss. Die geographische Herkunft der Blattproben erklärte weitgehend die Variabilität der Streuqualität und Blattabbaurate. Die Konzentrationen von Phosphor (0.034-0.187\%) und Lignin (3.9-18.7\%) in den Blättern variierten stark. Zusammen bestimmten diese beiden Faktoren die Laubabbaurate sehr genau $\left(r^{2}=84.1 \%\right)$. Der intraspezifische $\mathrm{V}$ ariationsbereich d er B lattabbaurate än elte d em interspezifischen Variationsbereich für gemeinsam auftretende europäische Ufergehölzarten. Unsere Untersuchung zeigte große intraspezifische Variabilität $\mathrm{d}$ er B latteigenschaften i m k ontinentalen M aßstab, w as e rhebliche A uswirkungen auf wichtige ökosystemare Prozesse wie die Streuzersetzung haben kann.

Keywords: Ecosystem functioning; Litter breakdown; Litter quality; Species traits; Trees

\footnotetext{
${ }^{*}$ Corresponding author. Current address: Department of Forest Sciences, University of British Columbia, Vancouver, BC, Canada V6T 1 Z4. Tel.: + 16048228927 ; fax: + 16048229102 .

E-mail address: Antoine.Lecerf@ubc.ca (A. Lecerf).
} 


\section{Introduction}

Plant functional traits are relevant to examine how plants respond to their environment and conversely how they alter ecosystem properties (Lavorel \& Garnier, 2002; Violle et al., 2007; Westoby \& Wright, 2006). Since leaves play a central role in the exchange of energy and nutrients between plants and their environment, particular attention has been paid to the enormous interspecific differences in many leaf traits (Wright et al., 2004). Complementary issues on variability in leaf traits within species have been much less extensively addressed, conceivably because current evidence supports the general idea that intraspecific variations are generally much smaller than interspecific differences (Garnier et al., 2001; Roche, Díaz-Burlinson, \& Gachet, 2004).

Intraspecific variability in leaf traits can alter organic matter dynamics in soil and streams. Some investigators have found that decomposition rate of senescent leaves varies among individual populations, plants, and leaves (Sariyildiz \& Anderson, 2003; Silfver, Mikola, Rousi, Roininen, \& Oksanen, 2007; Treseder \& Vitousek, 2001). These variations were attributed to differences in litter quality, a notion encompassing a suite of physical and chemical traits, which affect leaf utilization by consumers (Cadish \& Giller, 1997). Besides being controlled by litter consumers and abiotic factors, leaf decomposition rate is thus also regulated intrinsically by nutrient $(\mathrm{N}, \mathrm{P})$ content and concentration of refractory compounds such as lignin and phenolics (e.g., Enriquez, Duarte, \& Sand-Jensen, 1993; Gessner \& Chauvet, 1994; Ostrofsky, 1997; Valachovic, Caldwell, Cromack, \& Griffiths, 2004).

While researchers have focused on genetic and environmental determinants of intraspecific variability in leaf traits (e.g. Cornelissen \& Stiling, 2005; Koricheva, Larsson, Haukioja, \& Keinänen, 1998; Madritch \& Hunter, 2005; Whitham et al., 2006), only a few studies have investigated temporal and spatial variation patterns. Large variations may occur in widely distributed species, the rationale being that strong biogeographic, climatic and ecological gradients would promote genetic differentiation and phenotypic plasticity in plants (Cordell, Goldstein, Mueller-Dombois, Webb, \& Vitousek, 1998). Since alder (Alnus glutinosa Gaertn.) is a major component of riparian vegetation in Europe (Prat, Leger, \& Bojovic, 1992), it can be used to assess intraspecific variability at the continental scale. Alder supplies stream food webs with large amounts of deciduous leaves, a high quality substrate to microbial decomposers and detritivore invertebrates (Hieber \& Gessner, 2002; Lecerf, Dobson, Dang, \& Chauvet, 2005).

This study was designed to assess the extent of variation in quality and decomposition rate of senescent alder leaves across Europe. More specifically we determined seven leaf traits in leaf samples originating from five geographically distant locations and examined the relationships between leaf traits and leaf decomposition rate in coarse and fine mesh bags exposed a single stream. Variation among locations was compared to local sources of variation assessed in each location; in addition, we compared intraspecific variation in alder leaf decomposition rate observed in this experiment to the interspecific variability reported in previous studies.

\section{Materials and methods}

\section{Origin, selection and collection of leaf litter}

Senescent leaves of alder were collected in European sites near the cities of Umeå (Sweden), Manchester (England), Lucerne (Switzerland), Toulouse (France) and Coimbra (Portugal). The five sampling sites were located far apart from each other $(>650 \mathrm{~km})$ and encompassed a broad latitudinal gradient $\left(40.3-64.1^{\circ} \mathrm{N}\right)$. All leaves were collected in autumn 2002, with the exception of France, where an additional collection was made in autumn 2003. Senescent leaves were either picked from trees or collected from the forest floor just after leaf fall. After air-drying to constant weight, the leaves collected in Umeå, Manchester, Lucerne, and Coimbra were sent to Toulouse, France, for determination of leaf traits in the laboratory and decomposition rates in a single stream.

Two contrasting batches of leaf samples were collected from a single area at each location with the aim to distinguish the intraspecific continental variability from the local sources of variation. We applied different criteria in each location for the leaf selection to increase the chances of encompassing all major sources of sampling-induced variability (Table 1). Outcomes from previous studies suggest that the date of leaf collection and discrimination among leaf types or tree habitats while sampling are important sources of intraspecific variation in leaf traits (Cornelissen et al., 2000; Cornelissen \& Stiling, 2005; Gill, Amthor, \& Bormann, 1998; Sariyildiz \& Anderson, 2003; Tibbets \& Molles, 2005; Treseder \& Vitousek, 2001). In this experiment, two leaf samples were collected from a single alder stand in Sweden at a 1-month interval. In France, leaves collected in autumn of 2002 were compared to those from the same trees collected 1 year later, after an exceptional summer heat wave. The two leaf samples originating from the same sets of trees in England and Switzerland differed according to their physical traits (Table 1), with the sun leaves being smaller and thicker than the shade leaves (Sariyildiz \& Anderson, 2003). In Portugal, the leaves were collected from two nearby alder stands growing in different habitats (streamside and floodplain) and hence may 


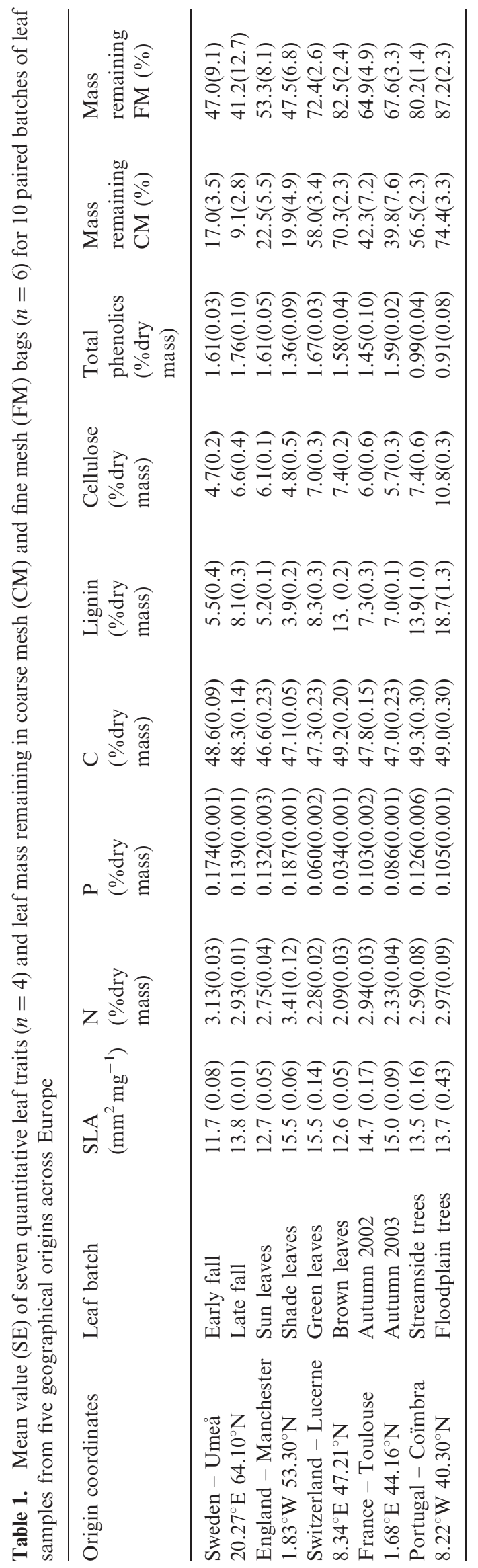

have been exposed to different levels of water and nutrients (Tibbets \& Molles, 2005).

\section{Leaf traits}

Four sub-samples (ca. $4 \mathrm{~g}$ ) of each leaf batch were used for leaf trait determination. Five randomly selected leaves were rewetted with deionized water, and then two 10 -mm discs were cut from each leaf, avoiding the central vein. The 10 leaf discs were dried at $105^{\circ} \mathrm{C}$ for $48 \mathrm{~h}$ and weighed to the nearest $0.1 \mathrm{mg}$ to determine specific leaf area (SLA $=$ ratio of leaf area to mass), a measure of leaf toughness. The non-wetted leaf material was finely ground in a micro-hammer mill $(0.5 \mathrm{~mm}$ mesh screen, Culatti, Switzerland) for later determination of leaf dry mass and chemistry.

Leaf carbon (C) and nitrogen (N) concentrations were determined using a CHN-analyser (NA 2100, CEInstruments, ThermoQuest, Milan, Italy), while phosphorus concentration (P) was determined by the ascorbic acid colorimetric method after ash-digestion in $\mathrm{HCl}$ as described by Flindt and Lillebø (2005). Total phenolics were determined by the Folin-Ciocalteu method after acetone extraction (Bärlocher \& Graça, 2005). Lignin and cellulose were determined using the acid-detergent fiber procedure as described by Gessner (2005).

\section{Leaf decomposition}

Total and microbial decomposition rates for the 10 leaf batches were determined in coarse $(10-\mathrm{mm})$ and fine $(0.5-\mathrm{mm})$ mesh bags, respectively. The coarse mesh allowed the largest leaf-consuming invertebrates to access the leaves, whereas the fine mesh excluded most of the invertebrates without limiting microbial colonization (Lecerf et al., 2005). Leaf bags consisted of $5 \mathrm{~g}$ of air-dried leaves which were sprayed with deionized water after being weighed to prevent leaf breakage during handling and transport to the field. Six replicates of coarse and fine mesh bags were installed on November 26, 2003 in a second-order forested stream located in the Massif Central (France, latitude N $43^{\circ} 25^{\prime} 29.5^{\prime \prime}$, longitude E $2^{\circ} 13^{\prime} 29.3^{\prime \prime}$, altitude $720 \mathrm{~m}$ a.s.1.), in six separate riffles. Meanwhile, a separate experiment involving 10 leaf species decomposing in coarse mesh bags was conducted in the same stream [see Lecerf, Risnoveanu, Popescu, Gessner, and Chauvet (2007) for further details on the stream characteristics and previous experiment]. Combining the results of the present and previous experiments provided a robust comparison of the magnitude of intraspecific versus interspecific variability in leaf decomposability.

In the present experiment, leaf bags were retrieved after 23 days in the stream and stored individually in 
plastic zip-lock bags at stream temperature during transport to the laboratory. In the laboratory the leaves were washed individually with tap water to remove sand and exogenous particulate organic matter, dried at $105^{\circ} \mathrm{C}$ for $48 \mathrm{~h}$ and weighed to the nearest $0.01 \mathrm{~g}$. Decomposition rates in coarse and fine mesh bags were assessed as percent of leaf dry mass remaining.

\section{Data analysis}

Nested MANOVA was used to assess whether leaf traits and leaf decomposition rates depended on location and leaf batch within location (Table 1). Sum of squares derived from variance partitioning by canonical redundancy analysis after standardization of the variables $(x-\mu) / \sigma$ and $P$-values were given by permutation tests (Anderson \& Ter Braak, 2003). The effect of leaf batch provided the most suitable error term to test for the effect of location. The residual error term was used to test for the effect of leaf batch. Nested ANOVA based on the same statistical design was used to test for the effects of location and batch on individual leaf traits and leaf mass remaining in coarse and fine mesh bags. Riffle was used as a blocking factor in the nested ANOVA on decomposition data. Data were logtransformed to improve homoscedasticity and normality when necessary.

Mean value of leaf traits $(n=4)$ and leaf mass remaining in coarse and fine mesh bags $(n=6)$ was calculated for each of the 10 leaf batches. Pearson's correlation coefficient was then calculated to test for covariation among leaf parameters. Partial least squares (PLS) regression was carried out to identify the leaf traits that best explained leaf decomposition rate based on regression coefficients (Höskuldsson, 1988). Significant predictors were then introduced in a forward multiple linear regression analysis based on ordinary least squares (type I sum of squares) with $P$ required to enter a predictor set at $<0.1$.

Nested MANOVA was performed by a program written by $P$. Legendre (NESANOVA; University of Montréal, http://www.bio.umontreal.ca/casgrain/fr/ labo/nesanova.html), and Statistica (version 6.0; Statsoft Inc., Tulsa, USA) was used to carry out nested ANOVA and simple and multiple regression analyses. SIMCA-P (version 9.0; Umetrics AB, Umeå, Sweden) was used to perform PLS regression.

\section{Results}

\section{Leaf traits}

Traits of senescent alder leaves greatly varied across the 10 leaf batches (Table 1). P and lignin displayed the greatest ranges (up to 5.5- and 4.8-fold, respectively) whereas the other leaf traits varied by factors $<2.5$. Leaf traits varied significantly according to geographical origin (Nested MANOVA: $F_{4,5}=3.2, P=0.0099$ ) and leaf batch within location $\left(F_{5,30}=18.4, P=0.0001\right)$. Furthermore, the geographical origin explained $65.8 \%$ of the total variation in the dataset while the local sources of variation (leaf batch within location) represented $25.8 \%$. Nested ANOVA of individual leaf traits showed that $\mathrm{P}$, lignin and total phenolics varied significantly between location and leaf batches $(F>2.53$, $P<0.05)$, whereas SLA, N, C, and cellulose varied significantly only between leaf batches $\left(F_{5,30}>5.53\right.$, $P<0.001)$.

Leaf traits did not vary independently of one another. Strong correlations were found between lignin and cellulose $(r=0.931, P<0.0001)$, and between $\mathrm{N}$ and $\mathrm{P}$ $(r=0.899, P=0.0004)$. Lignin and total phenolics also showed significant co-variation $(r=-0.682, P=0.029)$. Other possible correlations were non-significant (cellulose versus total phenolics: $r=-0.619, P=0.056$; for all other combinations: $r<0.6, P>0.10$ ).

\section{Leaf decomposition}

There was a marked variation in mass remaining of alder leaves enclosed in coarse and fine mesh bags after 23 days (Table 1). The location of leaf origin explained most of the total variance $\left(66.4 \% ; \quad F_{4,5}=22.0\right.$, $P=0.0004)$. There was a negative relationship between leaf decomposition rates and latitude (Fig. 1). Variation among leaf batches (3.8\% of the total variance) was one order of magnitude lower than variation among locations. According to nested ANOVA including riffle as a blocking factor (coarse mesh bags: $F_{5,45}=7.27, P<$

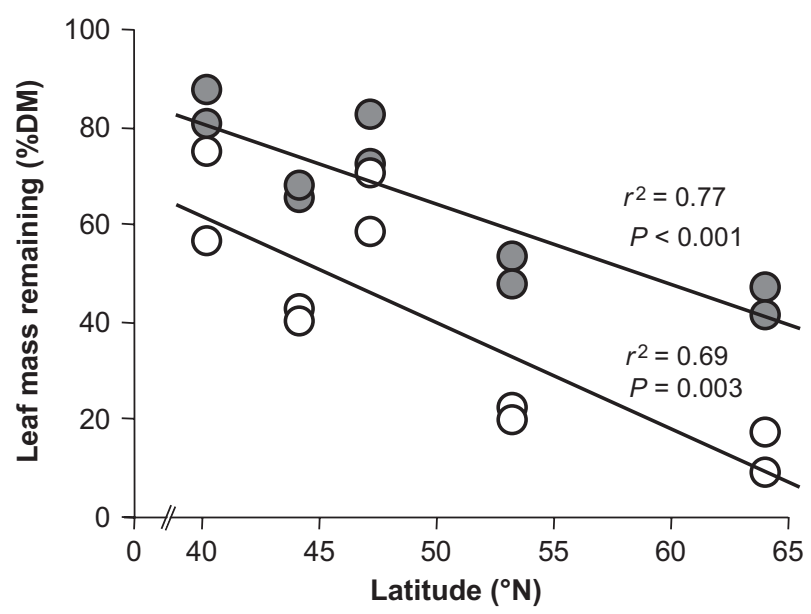

Fig. 1. Mass remaining of 10 batches of alder leaf samples decomposing in coarse (open dots) and fine (shaded dots) mesh bags in a stream as a function of latitude of leaf origin. 

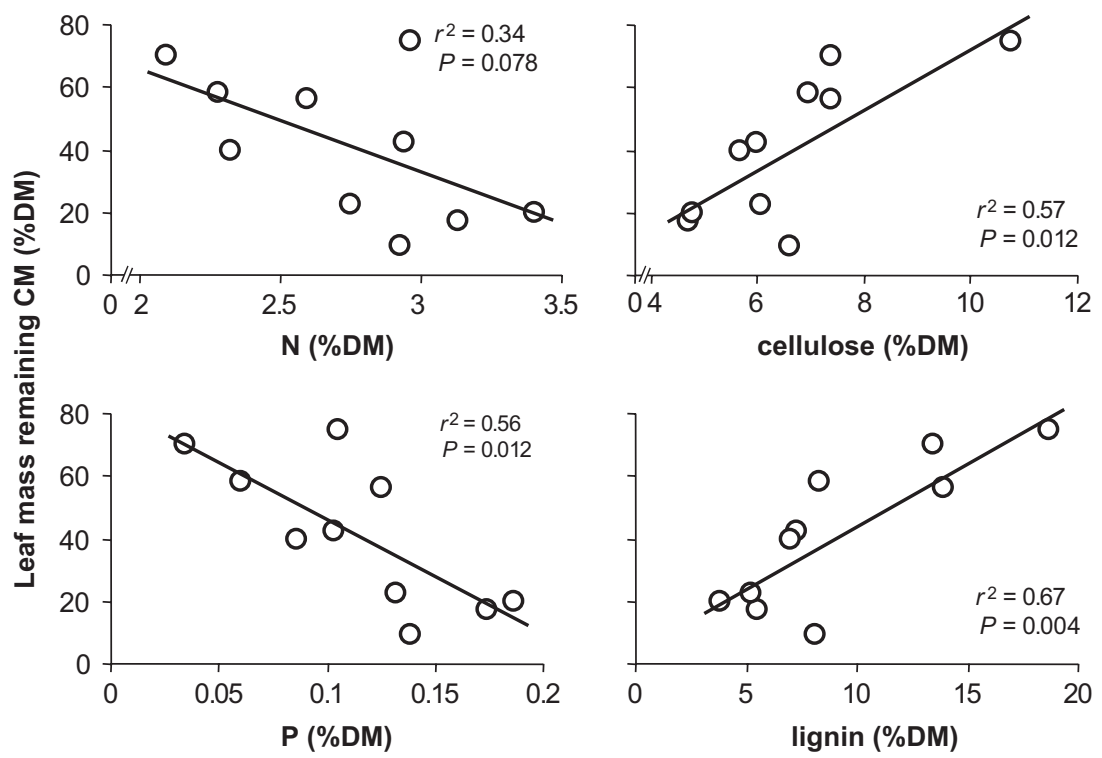

Fig. 2. Mass remaining of 10 batches of alder leaf samples decomposing in coarse mesh (CM) bags in a stream as a function of the four most influential leaf traits according to partial least squares regression (see Table 2).

Table 2. Partial least squares regression coefficients for leaf decomposition in coarse mesh (CM) and fine mesh (FM) bags

\begin{tabular}{lcc}
\hline Variables & $\begin{array}{l}\text { Leaf mass } \\
\text { remaining CM }\end{array}$ & $\begin{array}{l}\text { Leaf mass } \\
\text { remaining FM }\end{array}$ \\
\hline SLA & $-0.11(0.15)$ & $-0.11(0.08)$ \\
$\mathrm{N}$ & $-0.25(0.12)^{*}$ & $-0.28(0.08)^{*}$ \\
$\mathrm{P}$ & $-0.32(0.06)^{*}$ & $-0.31(0.06)^{*}$ \\
$\mathrm{C}$ & $0.06(0.15)$ & $0.04(0.12)$ \\
Lignin & $0.24(0.02)^{*}$ & $0.24(0.02)^{*}$ \\
Cellulose & $0.21(0.04)^{*}$ & $0.19(0.06)^{*}$ \\
Total phenolics & $-0.20(0.18)$ & $-0.26(0.22)$ \\
\hline
\end{tabular}

Notes: Both models are based on two principal components. Asterisks denote model coefficients that are significantly different from 0 as indicated by $95 \%$ confident interval derived from jackknifing.

0.0001; fine mesh bags: $F_{5,45}=2.3, P=0.0585$ ), differences among leaf batches from each location were significant for leaf mass remaining in coarse mesh bags $\left(F_{5,45}=2.9, P=0.0258\right)$, but not for leaf mass remaining in fine mesh bags $\left(F_{5,45}=0.5, P=0.73\right)$. However, leaf mass remaining in coarse and fine mesh bags varied across the treatments in a consistent manner $(r=0.985$, $P<0.0001)$. The difference in leaf decomposition rate between the two bag types was consistent with the high abundance of leaf-consuming invertebrates (mainly, Plecoptera and Trichoptera) in coarse mesh bags and their absence in fine mesh bags.

Leaf mass remaining in coarse mesh bags was accurately predicted by the seven leaf traits determined in this study. A PLS regression model based on two principal components explained $88.4 \%$ of the total variation. Notably, four traits had a significant influence on leaf mass remaining (Table 2). Lignin and cellulose were negatively related to decomposition rate as their coefficients of regression (slope) were positive. The opposite was true for N and P (Fig. 2). We conducted a forward multiple linear regression with these four traits to determine a minimal adequate model. This analysis showed that two leaf traits, $\mathrm{P}$ and lignin, together explained $84.1 \%$ of the total variation in leaf mass remaining in coarse mesh bags (equation model: \% leaf mass remaining $=-229 \times \mathrm{P}+3.0 \times$ lignin). Results were very similar when conducting regression analyses on leaf mass remaining in fine mesh bags (Table 2).

We used a daily decay coefficient calculated from data on leaf mass remaining in coarse mesh bags to compare decomposition data from different studies (Fig. 3). The overall range of intraspecific variation in alder leaf decomposition rate covered more than half of the full ranges of interspecific variation reported for wooded riparian plants from three European sites by Gessner and Chauvet (1994) and Lecerf et al. (2007). A close examination of data on 10 leaf species decomposing under conditions similar to the present study (cf. Lecerf et al., 2007) revealed that alder leaves can decompose faster than ash (Fraxinus excelsior) leaves, a very fast decomposing species, but also slower than oak (Quercus robur) leaves, one of the slowest decomposing species in riparian zones. Maple (Acer pseudoplatanus), birch (Betula pendula), elm (Ulmus minor) and hazel (Corylus avellana) were also within the range of variation of alder decomposition rate. Only beech (Fagus silvatica) leaves had a much slower decomposition rate than that of any batch of alder leaves. 


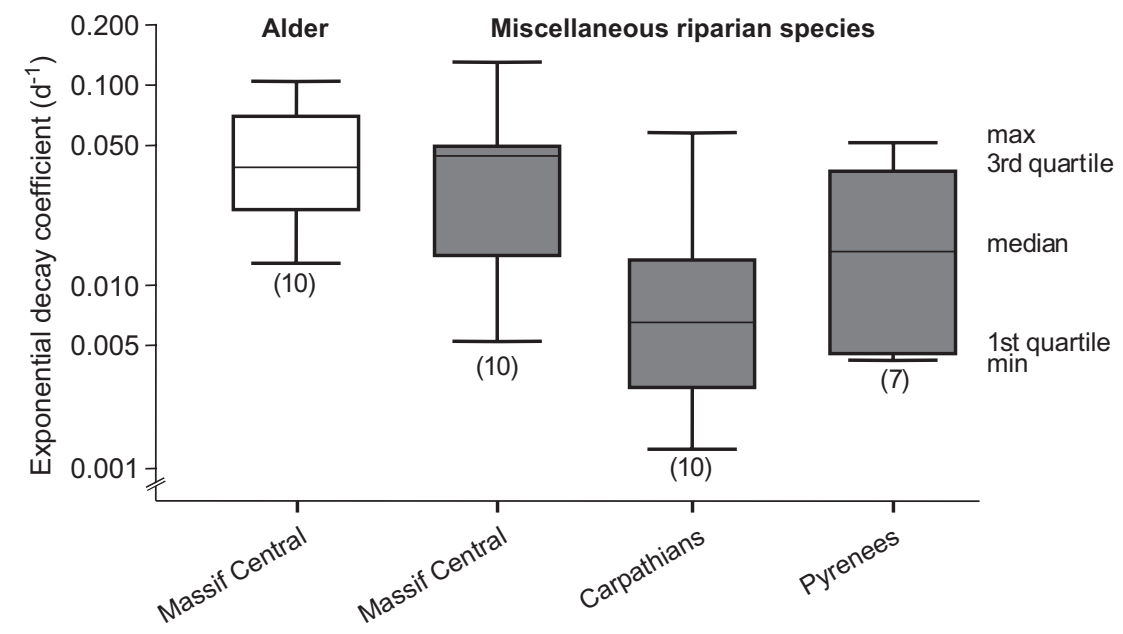

Fig. 3. Comparing intraspecific variation of in-stream decomposition rate of alder leaves (open box) to interspecific variation reported in the literature (shaded boxes). Multispecies data for the Massif Central and the Carpathians are from Lecerf et al. (2007) and data for the Pyrenees are from Gessner and Chauvet (1994). Exponential decay coefficients for the present study and those for Lecerf et al. (2007) were calculated from the formula: $k=-\ln (R) / t$, where $k$ is the exponential decay coefficient, $R$ the proportion of leaf mass remaining coarse mesh bags and $t$ the time of exposure. The number of batch/species is given in parentheses. Note the logarithmic scale on the vertical axis.

\section{Discussion}

Senescent alder leaves strongly differed among samples collected in five geographically distant locations across Europe. The most variable leaf traits had ranges (up to 5.5 -fold for $\mathrm{P}$ and 4.8 -fold for lignin) similar to those of interspecific variation reported for tree leaves at a European (Pyrenean) site [P-variation up to 5.5-fold and lignin-variation up to 4.5; Gessner and Chauvet (1994)]. Intraspecific variability in leaf decomposition was also remarkable, with a range of variation being widely comparable to ranges of interspecific variation among co-occurring woody plant species reported previously (Fig. 3). It is worth noting that this intraspecific continental variability cannot be simply accounted for by sampling-induced differences in leaf traits since the leaf decomposition rate was consistent with latitude whereas there were only small differences among the leaf batches in the five locations. Thus, while many studies suggest that intraspecific variability in leaf traits is a common plant property (e.g. Cordell et al., 1998; Garnier et al., 2001; Madritch \& Hunter, 2005; Silfver et al., 2007), our results demonstrate that this variability can have a considerable impact on important ecosystem processes such as leaf decomposition.

Our results are in accordance with the theory predicting that leaves with high nutrient content and low concentration of refractory compounds are decomposed faster by leaf consumers (Cadish \& Giller, 1997). The positive effect of $\mathrm{P}$ on decomposition rate is supported by experimental evidence suggesting that $\mathrm{P}$ is a major limiting factor for growth and activity of microbial and invertebrate decomposers in streams (Cross, Benstead, Rosemond, \& Wallace, 2003; Grattan
\& Suberkropp, 2001; Rosemond, Pringle, Ramirez, Paul, \& Meyer, 2002; Stallcup, Ardón, \& Pringle, 2006). Nitrogen limitation may have been comparatively weaker since high $\mathrm{N}$ concentration in leaves $(>2.1 \%)$ and large amount of dissolved inorganic nitrogen available to microbial decomposers (in-stream concentration $>1 \mathrm{~g} \mathrm{~N} \mathrm{~L}^{-1}$; Lecerf et al., 2007) potentially saturate the biological $\mathrm{N}$ demand in the leaf bags (Ferreira, Gulis, \& Graça, 2006). It is therefore possible that the correlation between $\mathrm{N}$ and leaf decomposition rate resulted from co-variation with $\mathrm{P}$ rather than indicating any regulating process involving $\mathrm{N}$ in this study. Regulation of leaf decomposition rate by lignin is supported by repeated reports of its negative effect in decomposition experiments conducted in both aquatic and terrestrial environments (e.g. Gessner \& Chauvet, 1994; Ostrofsky, 1997; Valachovic et al., 2004) and the fact that lignin is the most refractory organic compounds in plant litter (Cadish \& Giller, 1997).

While litter quality controlled leaf decomposition, phenotypic plasticity and genotypic variation may be the determinants of intraspecific variation in leaf traits (Cordell et al., 1998; Whitham et al., 2006). Since leaf samples collected in a given location originated from a single population or even a single genotype (leaves from the same tree), the local variability observed here could be attributed largely to phenotypic plasticity of leaves in response to spatial and temporal differences in environmental factors such as light intensity, temperature or resource supplies (e.g. Koricheva et al., 1998; Tibbets \& Molles, 2005; Treseder \& Vitousek, 2001; present study cf. Table 1). At the continental scale, intraspecific variability may have also been determined by genotype since strong genetic differentiation between populations 
have been demonstrated for alder (King \& Ferris, 1998; Prat et al., 1992) and plant genes have been found to regulate litter quality and decomposability (Madritch \& Hunter, 2005; Silfver et al., 2007; Whitham et al., 2006). However, some traits (SLA, N, C and cellulose) did not significantly vary among locations in this study, suggesting that not all leaf traits are equally affected by genotype. A rational explanation for the small $\mathrm{N}$ variation is that $\mathrm{N}$ uptake by alder is primarily regulated by symbiotic $\mathrm{N}$ fixers rather than the plant alone.

Our study demonstrates that intraspecific variability in alder leaf traits and decomposition rate can be sufficiently large to override interspecific differences among co-occurring plants, at least of the same growth form (i.e., woody plants). This finding questions the relevance of the concept of species in ecological theories and studies dealing with the interplay between plant communities and ecosystem functions (see also Crutsinger et al., 2006). Although further investigations are needed to assess whether our results can be generalized to other plant species, leaf traits and ecological processes, this study suggests that caution must be exercised when large databases of leaf species traits determined in a few locations are used in macroecological studies (e.g., Wright et al., 2004). Measuring leaf species traits by site of interest represents a more reliable strategy for trait database constitution (e.g., Garnier et al., 2006).

\section{Acknowledgements}

We are indebted to B.G. McKie (University of Umeå, Sweden), H.M. Cariss (Manchester Metropolitan University), S.D. Tiegs (ETH-EAWAG, Kastanienbaum, Switzerland) and M.A.S. Graça (IMAR, University of Coïmbra, Portugal) for collecting and sending us the alder leaves and to D. Lambrigot and C. Pelissier for their technical help. We acknowledge M.O. Gessner, T.G. Martin, X. Pinto, E. Garnier, and two anonymous reviewers for valuable comments on early drafts of the manuscript. This research was carried out with financial support from the EU Commission within the RivFunction project (contract EVK1-CT-2001-00088). A postdoctoral grant from the Forest Science Program (BC, Canada) provided additional support for A.L. while writing this paper.

\section{References}

Anderson, M. J., \& Ter Braak, C. J. F. (2003). Permutation tests for multi-factorial analysis of variance. Journal of Statistical Computation and Simulation, 73, 85-113.

Bärlocher, F., \& Graça, M. A. S. (2005). Total phenolics. In M. A. S. Graça, F. Bärlocher, \& M. O. Gessner (Eds.),
Methods to study litter decomposition: A practical guide (pp. 97-100). Dordrecht: Springer.

Cadish, G., \& Giller, K. E. (1997). Driven by nature: Plant litter quality and decomposition. Wallingford: CAB international.

Cordell, S., Goldstein, G., Mueller-Dombois, D., Webb, D., \& Vitousek, P. M. (1998). Physiological and morphological variation in Metrosideros polymorpha, a dominant Hawaiian tree species, along an altitudinal gradient: The role of phenotypic plasticity. Oecologia, 113, 188-196.

Cornelissen, J. H. C., Pérez-Harguindeguy, N., Gwynn-Jones, D., Diaz, S., Callaghan, T. V., \& Aerts, R. (2000). Autumn leaf colours as indicators of decomposition rate in sycamore (Acer pseudoplatanus L.). Plant and Soil, 225, 33-38.

Cornelissen, T., \& Stiling, P. (2005). Perfect is best: Low leaf fluctuating asymmetry reduces herbivory by leaf miners. Oecologia, 142, 46-56.

Cross, W. F., Benstead, J. P., Rosemond, A. D., \& Wallace, J. B. (2003). Consumer-resource stoichiometry in detritusbased streams. Ecology Letters, 6, 721-732.

Crutsinger, G. M., Collins, M. D., Fordyce, J. A., Gompert, Z., Nice, C. C., \& Sanders, N. J. (2006). Plant genotypic diversity predicts community structure and governs an ecosystem process. Science, 313, 966-968.

Enriquez, S., Duarte, C. M., \& Sand-Jensen, K. (1993). Patterns in decomposition rates among photosynthetic organisms: The importance of detritus $\mathrm{C}: \mathrm{N}: \mathrm{P}$ content. Oecologia, 94, 457-471.

Ferreira, V. F., Gulis, V., \& Graça, M. A. S. (2006). Wholestream nitrate addition affects litter decomposition and associated fungi but not invertebrates. Oecologia, 149, 718-729.

Flindt, M. R., \& Lillebø, A. I. (2005). Determination of total nitrogen and phosphorus in leaf litter. In M. A. S. Graça, F. Bärlocher, \& M. O. Gessner (Eds.), Methods to study litter decomposition: A practical guide (pp. 45-50). Dordrecht: Springer.

Garnier, E., Laurent, G., Bellmann, A., Debain, S., Berthelier, P., Ducout, B., et al. (2001). Consistency of species ranking based on functional leaf traits. New Phytologist, 152, 69-83.

Garnier, E., Lavorel, S., Ansquer, P., Castro, H., Cruz, P., Dolezal, J., et al. (2006). Assessing the effects of land-use on plant traits, communities and ecosystem functioning in grasslands: A standardized methodology and lessons from an application to 11 European sites. Annals of Botany, $1-19$.

Gessner, M. O. (2005). Proximate lignin and cellulose. In M. A. S. Graça, F. Bärlocher, \& M. O. Gessner (Eds.), Methods to study litter decomposition: A practical guide (pp. 103-108). Dordrecht: Springer.

Gessner, M. O., \& Chauvet, E. (1994). Importance of stream microfungi in controlling breakdown rates of leaf litter. Ecology, 75, 1807-1817.

Gill, D. S., Amthor, J. S., \& Bormann, F. H. (1998). Leaf phenology, photosynthesis, and the persistence of saplings and shrubs in a mature northern hardwood forest. Tree Physiology, 18, 281-289.

Grattan, R. M., \& Suberkropp, K. (2001). Effects of nutrient enrichment on yellow poplar leaf decomposition and fungal 
activity in streams. Journal of North American Benthological Society, 20, 33-43.

Hieber, M., \& Gessner, M. O. (2002). Contribution of stream detritivores, fungi, and bacteria to leaf breakdown based on biomass estimates. Ecology, 83, 1026-1038.

Höskuldsson, A. (1988). PLS regression methods. Journal of Chemometrics, 2, 211-228.

King, R. A., \& Ferris, C. (1998). Chloroplast DNA phylogeography of Alnus glutinosa (L.) Gaertn. Molecular Ecology, 7, 1151-1161.

Koricheva, J., Larsson, S., Haukioja, E., \& Keinänen, M. (1998). Regulation of woody plant secondary metabolism by resource availability: Hypothesis testing by means of meta-analysis. Oikos, 83, 212-226.

Lavorel, S., \& Garnier, E. (2002). Predicting changes in community composition and ecosystem functioning from plant traits: Revisiting the Holy Grail. Functional Ecology, $16,545-556$.

Lecerf, A., Dobson, M., Dang, C. K., \& Chauvet, E. (2005). Riparian plant species loss alters trophic dynamics in detritus based stream ecosystems. Oecologia, 146, 432-442.

Lecerf, A., Risnoveanu, G., Popescu, C., Gessner, M. O., \& Chauvet, E. (2007). Decomposition of diverse litter mixtures in streams. Ecology, 88, 219-227.

Madritch, M., \& Hunter, M. D. (2005). Phenotypic variation in oak litter influences short- and long-term nutrient cycling through litter chemistry. Soil Biology and Biochemistry, 37, 319-327.

Ostrofsky, M. L. (1997). Relationship between chemical characteristics of autumn-shed leaves and aquatic processing rates. Journal of the North American Benthological Society, 16, 750-759.

Prat, D., Leger, C., \& Bojovic, S. (1992). Genetic diversity among Alnus glutinosa (L.) Gaertn. populations. Acta Oecologica, 13, 469-477.

Roche, P., Díaz-Burlinson, N., \& Gachet, S. (2004). Congruency analysis of species ranking based on leaf traits: Which traits are the more reliable? Plant Ecology, 174, 37-48.

Rosemond, A. D., Pringle, C. M., Ramirez, A., Paul, M. J., \& Meyer, J. L. (2002). Landscape variation in phosphorus concentration and effects on detritus-based tropical streams. Limnology and Oceanography, 47, 278-289.

Sariyildiz, T., \& Anderson, J. M. (2003). Decomposition of sun and shade leaves from three deciduous tree species, as affected by their chemical composition. Biology and Fertility of Soils, 37, 137-146.

Silfver, T., Mikola, J., Rousi, M., Roininen, H., \& Oksanen, E. (2007). Leaf decomposition differs among genotypes in a local Betula pendula population. Oecologia, 152, 707-714.

Stallcup, L. A., Ardón, M., \& Pringle, C. M. (2006). Does nitrogen become limiting under high-P conditions in detritus-based tropical streams? Freshwater Biology, 51, $1515-1526$.

Tibbets, T. M., \& Molles, M. C., Jr. (2005). C:N:P stoichiometry of dominant riparian trees and arthropods along the Middle Rio Grande. Freshwater Biology, 50, $1882-1894$.

Treseder, K. K., \& Vitousek, P. M. (2001). Potential ecosystem-level effects of genetic variation among populations of Metrosideros polymorpha from a soil fertility gradient in Hawaii. Oecologia, 126, 266-275.

Valachovic, Y. S., Caldwell, B. A., Cromack, K., Jr., \& Griffiths, R. P. (2004). Leaf litter chemistry controls on decomposition of Pacific Northwest trees and woody shrubs. Canadian Journal of Forest Research, 34, 2131-2147.

Violle, C., Navas, M.-L., Vile, D., Kazakou, E., Fortunel, C., Hummel, I., et al. (2007). Let the concept of trait be functional!. Oikos, 116, 882-892.

Westoby, M., \& Wright, I. J. (2006). Land-plant ecology on the basis of functional traits. Trends in Ecology and Evolution, 21, 261-268.

Whitham, T. G., Bailey, J. K., Schweitzer, J. A., Shuster, S. M., Bangert, R. K., LeRoy, C. J., et al. (2006). A framework for community and ecosystem genetics: From genes to ecosystems. Nature Reviews Genetics, 7, 510-523.

Wright, I. J., Reich, P. B., Westoby, M., Ackerly, D. D., Baruch, Z., Bongers, F., et al. (2004). The worldwide leaf economics spectrum. Nature, 428, 821-827. 